https://helda.helsinki.fi

\title{
Language of Law and Invasive Legal Species : Endemic Systems, Colonisation, and Viability of Mixed Law
}

\section{Husa, Jaakko}

2020-06-30

Husa , J 2020 , ' Language of Law and Invasive Legal Species : Endemic Systems,

Colonisation, and Viability of Mixed Law ' , Global journal of comparative law , vol. 9 , no. 2 , pp. 149-182 . https://doi.org/10.1163/2211906X-00902001

http://hdl.handle.net/10138/331642

https://doi.org/10.1163/2211906X-00902001

cc_by_nc

acceptedVersion

Downloaded from Helda, University of Helsinki institutional repository.

This is an electronic reprint of the original article.

This reprint may differ from the original in pagination and typographic detail.

Please cite the original version. 


\title{
LANGUAGE OF LAW AND INVASIVE LEGAL SPECIES - ENDEMIC SySTEMS, COLONiSATION, AND VIABILITY OF MIXED LAW
}

\author{
Jaakko Husa \\ Professor in Law and Globalisation \\ University of Helsinki
}

\section{Introduction}

It is difficult to overstate the importance of language to the study of law. For legal linguists and translators the bond between law and language is the bread and butter of their disciplines. ${ }^{1}$ Philosophy of law is, as is well known, intimately intertwined with language; there are legal theories built on language. ${ }^{2}$ Among comparative legal scholars and legal historians, too, it is an acknowledged fact that law and language are entangled. We need only look at what kind of legal languages common law and civil law have produced in order to grasp the importance of the surrounding legal culture and language of law. ${ }^{3}$ As a result, it would be impossible to think of common law without English, civil law without Romance and Germanic languages, or Islamic law without the Arabic language. Language is an important - though certainly not the only - context of law. Tamanaha has rightly noted that '[1]aw cannot deliver in and of itself because it swims in the social sea with everything else'. ${ }^{4}$ Language, it is argued in this article, is an exceptionally relevant part of the social sea that Tamanaha speaks about. How law swims in that social sea takes place through language. ${ }^{5}$

All the above is so evident that it may appear trivial. Of course, all fields of legal scholarship at least implicitly recognise - and are based in one way or another on - the language of law. In terms of traditional legal disciplines, comparatists and historians have perhaps the most obvious link to conceiving the intimate relation between languages and law simply because they work with legal texts that are in different languages. Sometimes this relation is virtually an

\footnotetext{
${ }^{1}$ Legal linguistics typically starts from a simple but fundamental assumption according to which 'law and language are closely related', Marcus Galdia, Legal Linguistics (Peter Lang 2009) 27. See also Heikki ES Mattila, Comparative Legal Linguistics (2nd edn, Routledge 2016) 1-2.

${ }^{2}$ See, eg, Marta Andruszkiewicz, 'On Some of Aspects of the Linguistic Theory of Law' (2016) 46 Studies in Logic, Grammar and Rhetoric 211 (discusses Jürgen Habermas, Jerzy Wroblewski, Robert Alexy, and HLA Hart).

${ }^{3}$ Cf Peter M Tiersma, 'A History of the Languages of Law' in Peter M. Tiersma (ed), The Oxford Handbook of Language and Law (OUP 2016).

${ }^{4}$ Brian Z Tamanaha, 'The Primacy of Society and the Failures of Law and Development' (2011) 44 Cornell Intl LJ 209, 247.

${ }^{5}$ Cf Mattila (n 1) 136 (stressing that law is always linked to the culture of a society).
} 
unsurmountable obstacle, as it has been and still largely is the case with Chinese law and Western scholars. ${ }^{6}$ Only with a little stretching of the argument can we claim that law in itself is a language. ${ }^{7}$ This foundational relationship is, however, filled with tension especially in mixed legal systems because language indicates legal and cultural identity in non-monolingual surroundings. ${ }^{8}$ This issue is not so pertinent to monolingual, non-mixed systems. ${ }^{9}$

This article, in essence, discusses the congruence between legal culture and language of law. It is intended to identify and analyse key factors that bear significance to the viability of smaller legal systems experiencing transformative impulses from a neighbouring strong legal culture. The argument is based principally on the notion of legal linguistic endemism that is proposed in the article. Drawing on ecology and legal linguistics, this article provides a novel conceptualisation on the significance of linguistic factors to the viability of a legal culture of a mixed jurisdiction. The argument is explained and tested with four illustrative cases - legal systems - that allow at least tentative theory-building. The cases addressed are Hong Kong, Scotland, Quebec, and Louisiana. Three of these are classified as mixed legal systems, whereas Hong Kong has been regarded as a common law system. In this article, however, Hong Kong is regarded as a mixed legal system when seen from the point of view of macro-comparative law. Now, it is beneficial to keep in mind that a macro-comparative view to a legal system is a specific one and does normally not coincide with a lawyer's view.

In macro-comparison, contrasting takes place between legal systems or between legal cultures. In other words, the levels of abstraction and generalisation are both high. Macrocomparison does not concentrate on individual legal rules, cases, institutions or concrete problems and ways to solve them, which is the case in micro-comparison. Macro-comparison may, for example, be aimed at issues that concern legislative methods, the style of writing provisions, the systematisation and division of the different fields of law and the doctrine of legal sources, language, or the style of entire legal systems, ie legal cultural features characteristic of those systems. Today, the two most important and virtually overarching legal cultures are civil law and common law. ${ }^{10}$ However, not all systems can be classified as civil law or common law. This in turn

\footnotetext{
${ }^{6}$ Teemu Ruskola, Legal Orientalism - China, the United States, and Modern Law (Harvard University Press 2013) 467.

${ }^{7}$ H Patrick Glenn, Legal Traditions of the World (4th edn, OUP 2010) 164.

${ }^{8}$ Cf Vernon Valentine Palmer, 'Introduction and Comparative Overview' in Vernon Valentine Palmer (ed), Mixed Jurisdictions Worldwide (2nd edn, CUP 2012) 3, 51-2.

${ }^{9}$ There are also cases where two versions of the same language compete against each other, as Greece and Norway demonstrate, see Mattila (n 1) 75-85. There are also systems where there are more official languages, for instance, Switzerland, see Pascal Pichonnaz, 'Legal Interpretation in Multilingual States' (2017) 12 J Comp L 124 (arguing that multilingualism may be an opportunity, not a threat).

${ }^{10}$ See, eg, Thomas Lundmark, Charting the Divide between Common and Civil Law (OUP 2012).
} 
poses an epistemic challenge caused by hybridity. ${ }^{11}$ Hybridity refers to a mixture of different elements, mixité, resulting in a mixed composition of rules, principles and institutions whose elements are derived from different legal cultural spheres. ${ }^{12}$

Essentially, a mixed legal system refers to a system that simultaneously contains key characteristics of at least two legal cultures. Reasons for hybridity are always related to legal history, yet each legal system has followed different routes to hybridity. For example, together with British imperialism, common law spread to areas where other types of law (indigenous, traditional, and religious) had earlier been used. Gradually, these systems were merged together to produce features of both local law and common law. Mixed legal systems are nowadays seen by some as an independent legal family, which are by no means dying out, and are epistemologically equal to common law and civil law. ${ }^{13}$ However, the viability of mixed systems differs from case to case. This article develops an argument that seeks to explain the significance of legal language for a mixed legal system and its viability, using four illustrative examples as instances that provide historical and empirical material supporting the key argument. The approach in this study can be characterised as linguistically sensitive comparative law, which means that this is not a study in legal linguistics or an empirical study of courtroom discourse. ${ }^{14}$

The remainder of this article is divided into five sections. First, the theoretical base of endemism and legal culture is laid out. Thereafter, the symbiotic relationship between endemic legal language and viability of legal culture is outlined. This is followed by illustrative case studies of four legal systems. The last section draws on the preceding sections to summarise conclusions and to present the key argument on the role of legal language to the viability of endemic mixed legal systems.

\footnotetext{
${ }^{11}$ Although the notion of 'mixed legal system' is widely used in comparative law it is not, however, always completely clear what is meant by mixed law: what the mixité consists of, what its building blocks are, and what types of mixité exist. See Andreas Rahmatian, 'Alchemistic Metaphors in Comparative Law: Mixed Legal Systems, Reception of Laws and Legal Transplants' (2018) 11 Civil L Studies 231 (discusses mixed law and legal transplants against the backdrop of alchemy).

${ }^{12}$ See Seán Patrick Donlan, 'Comparative Law and Hybrid Legal Traditions - an Introduction', in Eleanor CashinRitaine, Seán Patrick Donlan, and Martin Sychold (eds), Comparative Law and Hybrid Legal Traditions (Swiss Institute of Comparative Law 2010) (arguing that hybridity challenges legal nationalism, positivism, centralism, and monism, which are all part of the 'legal families' approach).

${ }^{13}$ Cf Jaakko Husa, A new Introduction to Comparative Law (Hart, 2015) 215. This article does not use the notion of legal family but relies on a broad notion of legal culture that is explained in the above text.

${ }^{14}$ The approach in this article comes close to comparative legal linguistics; see Mattila (n 13) 11-20. See also Caroline Laske, 'Translators and Legal Comparatists as Objective Mediators between Cultures?' in Jaakko Husa and Mark van Hoecke (eds), Objectivity and Legal Reasoning (Hart 2013) (a deep-level and intrinsic link between law and language).
} 


\section{Endemism and Legal Cultures}

In order to be able to apply the notion of endemism to legal culture, we need first to clarify what this conceptualisation actually conveys and how it can be applied in the study of mixed legal systems. However, before it is possible to discuss endemism, it is necessary to explain how the slightly elusive notion of legal culture is used in this study.

Quintessentially, legal culture is a concept that is broader than a legal system. It refers to factors that appear outside the narrowly understood (ie formal) legal system but are closely related to the operation of the law; legal culture is about the context of law. Unlike the notion of a legal system, legal culture deals not only with rules, principles, doctrines and cases but also takes into account established attitudes to law - attitudes of a permanent nature adopted by jurists in particular (internal legal culture) and more extensively by human society (external legal culture). Essentially, legal culture refers to a system-specific way in which law-related values and practices and legal concepts are integrated in the actual operation of a legal system. In the legal cultural view, law is not conceived as autonomous but intimately connected to its human environment. ${ }^{15}$ For mixed systems, this is of importance because their mixité depends symbiotically on the contexts of law that enable or oppose mixité.

Another key point to remember is that legal culture is also a concept that refers to macro-comparative legal cultural spheres between groups of different systems. The overarching idea is that it is possible to distinguish groups of systems based on their use of use of legal sources, methods of legal argumentation or relation between law and religion so that, if these are broadly similar, then we can say that they belong to the same legal culture. Accordingly, we speak, for example, of common law, civil law, Islamic law, Hindu law, and Socialist law. ${ }^{16}$ Legal systems, on the other hand, belong to certain legal cultures. This is why we speak of common law systems, civil law systems, religious systems, and mixed systems. Importantly, mixed systems are typically - but not always - legal culturally endemic systems.

Endemism refers to 'the situation in which a species or other taxonomic group is restricted to a particular geographic region, owing to factors such as isolation or response to soil or climatic conditions. Such a taxon (taxa in the plural) is said to be endemic to that region. ${ }^{17}$ From

\footnotetext{
${ }^{15}$ Nelken says that legal culture 'in its most general sense, is one way of describing relatively stable patterns of legally oriented social behaviour and attitudes', David Nelken, 'Using The Concept of Legal Culture' (2004) 29 Australian J L Philosophy 1,1 .

${ }^{16}$ For a broader discussion, see Jaakko Husa, 'Macro-Comparative Law - Reloaded' (2018) 131 Tidsskrift for Rettsvitenskap 410.

${ }^{17}$ Michael Allaby, A Dictionary of Ecology (4th edn, OUP 2010).
} 
the geographical point of view, the key feature is that the borders of a region are determined by mapping the taxa distributions. In other words, a physical line delimits a biogeographic region. In biology, taxa are arranged in a hierarchy from kingdom to subspecies and a taxon normally includes several taxa of lower rank. The classification of protists includes different things such as plants and animals. Moreover, various other conceptualisations are used in descending order, for instance, kingdom, phylum (in plants, division), class, order, family, genus, species, and so on. ${ }^{18}$

Following the notion of endemism, certain species are endemic as to their nature. This means that species are native to, and restricted to, a particular geographical region. Now, endemic species are plants and animals that are defined by the fact that they exist only in one geographic region. There are no general rules concerning the size of an endemic species because species can be endemic to a larger or smaller geographic region. Accordingly, some species may be endemic to a particular continent, some to part of a continent, while others may be limited to a single island. Normally the case is such that a region containing endemic species is isolated. In practice, this means that it is difficult for the endemic species to spread to other areas. It may also be the case that in order to cope with their unusual environment, species have developed unique local adaptations. . Biologists also pay attention to hierarchical classifications by distinguishing genus, family, and order. These are parts of the hierarchical classification so that an order of plants or animals contains several families, each of these families includes several genera (plural of genus), and each genus has a number of species. The levels of this classification are called taxonomic levels. ${ }^{19}$ It is also possible to distinguish different kinds of endemic areas and, accordingly, biogeographical classifications are possible such as realms, regions, dominions, provinces, and districts. ${ }^{20}$

What is relevant for the present discussion is that endemic species may be threatened by so-called invasive species that have the potential capability to change habitats and alter the way in which an ecosystem functions and to displace or crowd out native endemic species. There is a fair amount of ambiguity in terms of defining an invasive species but, broadly, it refers to a species that is non-native (or alien) to a certain ecosystem. In any case, the introduction of such species typically causes environmental harm to the ecosystem in question. Invasive species can be animals, plants, and other organisms. ${ }^{21}$ How does all this fit into our discussion on mixed legal systems, legal language, and viability?

\footnotetext{
${ }^{18}$ Encyclopadia Britannica (https://www.britannica.com/science/endemic-species).

${ }^{19}$ Mary Ann Cunningham, 'Endemic Species' in Environmental Encyclopedia (2003) (https://www.encyclopedia.com).

${ }^{20} \mathrm{JJ}$ Morrone, 'Endemism' in Editors-in-Chief Sven Erik Jørgensen and Brian D Fath, Encyclopedia of Ecology (Elsevier 2008).

${ }^{21}$ Robert I Colautti and Hugh J MacIsaac, 'A neutral terminology to define 'invasive' species' (2004) 10 Diversity and Distributions 135.
} 
Before going further, it makes sense to make clear that ecological notions are not used here to create new classifications of legal systems; that is, the focus is on endemic mixed systems. The ecological notion of endemism is, rather, a tool for conceptualisation not a biological explanation of law. Essentially, mixed legal systems tend to be endemic so that their mixité is restricted to a particular region. Put differently, a mixed legal system contains a unique mixité of legal cultures.

In the world of law, there are also invasive species in the form of diffusion of law. This is conceptualised in various competing ways ranging from legal transplants to legal translations. ${ }^{22}$ For the present discussion, there is no need to delve in deep scholarly debate on the conceptualisation of legal diffusion. More importantly, it is crucial to ask this; if we conceive of a legal system as an endemic ecosystem of law, then what do we mean by invasive species? The issue of invading legal species concerns every legal system. However, there are differences between systems in this regard. Certain types of legal systems are more vulnerable than others. Arguably, we can say that common law and civil law systems in general are not particularly vulnerable even though legal diffusion certainly takes place. ${ }^{23}$ As a result, it seems safe to argue that vulnerability in particular concerns mixed legal systems, where different legal ingredients balance each other in a delicate symbiosis.

It is possible to regard a mixed legal system, like all legal systems, as an ecosystem of law that contains species that may become threatened by invasive legal species. Instead of animals, plants or other organisms, here we are dealing with species of law in the shape of legal rules, concepts, doctrines, precedents, or pieces of legislation. In this particular sense, a mixed legal system may become an endangered system. The notion of an endangered legal system is built on an idea according to which a system may be in danger of disappearing or being overwhelmed by outside elements. For a mixed legal system, this is an important question because invasive legal species may become so profuse that they endanger the balanced composition, or the symbiosis, of a mixed legal system. ${ }^{24}$ At the same time, this is not only about the quantity of invasive legal species

\footnotetext{
${ }^{22}$ See, eg, Esin Örücü, 'Law as Transposition' (2002) 51 ICLQ 205, Maximo Langer, 'From Legal Transplants to Legal Translations' (2004) 45 Harvard Intl L J 1, Zhangrun Xu, The Confucian Misgivings - Liang Shu-ming's Narrative About Law (Springer 2018) 169-187, and Mindy Chen-Wishart, 'Legal Transplant and Undue Influence: Lost in Translation or a Working Misunderstanding' (2013) 62 ICLQ 1.

${ }^{23}$ We can argue that all legal systems are mixed to a certain degree. Moreover, we need to bear in mind that there are different mixtures and when we are using the notion of mixed legal system we are necessarily simplifying. Cf Esin Örücü, 'Mixed and Mixing' in Esin Örücü, Elspeth Attwooll, and Sean Coyle (eds), Studies in Legal Systems (Kluwer 1996) (distinguishes mixing bowl systems, salad bowl systems, salad plate systems, and puree systems). See also Cornie Van der Merwe, 'The Origin and Characteristics of the Mixed Legal Systems of South Africa and Scotland and Their Importance in Globalisation' (2012) 18 Fundamina: a Journal of Legal History 91.

${ }^{24}$ See Sue Farran, Esin Örücü, Seán Patrick Donlan, 'An Introductory Overview' in Sue Farran, Esin Örücü, and Seán Patrick Donlan (eds), A Study of Mixed Legal Systems: Endangered, Entrenched or Blended (Ashgate 2014).
} 
but as well as, and perhaps even more so, about the underlying different legal logics that invasive species carry aided by language that enables invasive species to penetrate an endemic system.

An endangered legal system can be defined in the following manner:

'It is typically meant to refer to the potential loss of something viewed as valuable, as with endangered natural species. Obviously, not all legal traditions are so precious. Legal evolution can both improve and corrupt. ${ }^{25}$

The following section will discuss how language provides a route for invasive legal species, whereas the elements of preciousness, improvement, and corruption are left aside.

\section{Endemic Legal Language and Viability of a Mixed System}

The previous section dealt with endemism, the conceptual framework for this study. Importantly, endemism is not a bio-legal theory but a conceptual device for applying the idea of invasive legal species. This section addresses the role of language, invasive legal species and endemic mixed systems. Undoubtedly, it is not original to argue that the long-term survival of a mixed system is facilitated by - or perhaps even contingent upon - the presence of at least two official (or widely spoken languages) in that system. ${ }^{26}$ Accordingly, no novelty is claimed for this line of thought. However, the manner in which that claim is laid out in this study is new because this argument is constructed in a particularised manner.

From legal history we know that even the strongest of legal cultures are bound to change along with changes to the societal, political, religious, and linguistic environment. For instance, in terms of language, we know how Roman law transformed into Byzantine law following the mutation of legal language from Latin to Greek. ${ }^{27}$ For mixed legal systems and their viability, the critical issue concerns the linguistic underpinnings of legal culture prevalent in a system. Accordingly, the key question is the extent of the socio-linguistic infrastructure, which is crucial for

\footnotetext{
25 ibid 5.

${ }^{26}$ William Tetley, 'Mixed Jurisdictions: Common Law v. Civil Law (Codified and Uncodified)' (2000) 60 Louisiana L R 676 ('The long-term vitality of two legal systems in a mixed jurisdiction is greatly assisted, and may in fact be dependent upon, the official recognition of two languages, one of which is particularly associated with each legal system in question. The examples of Quebec, South Africa, Louisiana and Scotland are very telling in this regard', 726).

${ }^{27}$ See Jaakko Husa, 'Transformation of legal language - Early Byzantine legal discourse' (2017) 2 Intl J L Discourse 85.
} 
the sustainability of the mixed character of laws. ${ }^{28}$ In some cases, there is a difference between the spoken language and the source language of two kinds of legal culturally mixed laws. ${ }^{29}$ The crucial point here is that there is more than one legal language or, alternatively, that at some historical stage a linguistic difference has existed between legal languages. It is important to note that the concept of language used in this manner is a broad notion so that it incorporates the dominant legal ideology of a language community. ${ }^{30}$

It is argued here that legal language and legal cultural vicinity play a key role, especially for mixed systems. For example, Quebec's success in its defence of its civilian legal culture is due to its success in defending the position of French against the invasive impact of English. On the other hand, Louisiana's inability to effectively deflect the impact of Englishspeaking and common law-based American law has been significantly weakened by the loss of the French language and the supporting French-speaking socio-linguistic infrastructure. Scotland has lost much of its mixité because its legal language is in common with the surrounding English common law, whereas Hong Kong, at least for now, holds on to its common law culture by relying on English as its main language of law. ${ }^{31}$

However, caution must be applied when the role of legal language is addressed as a key factor for the viability of a legal system. Now, it is not argued here that language would be the only relevant factor in terms of ability to maintain a legal culture. ${ }^{32}$ Nevertheless, language is arguably an especially important factor for the ability of an endemic legal system to maintain its legal cultural viability as a mixed legal system. Importantly, the pivotal issue is not simply to maintain that language plays this kind of a general role but, rather, to conceptualise how invasive legal species penetrate and finally change the underlying nature of a legal system through language.

\footnotetext{
${ }^{28}$ Socio-linguistic infrastructure refers here to language in a societal context so that language is conceived in its relation to social and cultural factors. As an academic field, sociolinguistics aim to study the effects of language use in societies and the reciprocal effects of social organisation and social contexts on language use. In a socio-linguistic view, language is regarded as a social product with considerable variation along individual, community, cultural, and societal lines. For a more detailed discussion, see Christine Mallinson, 'Sociolinguistics' in Oxford Bibliographies Online DOI: 10.1093/obo/9780199772810-0039. Importantly, language is part of the general linguistic culture, Mattila (n 1) 72.

${ }^{29}$ Cf Palmer (n 8) 51-2.

${ }^{30}$ Cf Mark van Hoecke, 'Legal Cultures, Legal Traditions and Comparative Law' (2006) 3 Netherlands J L Philosophy 331.

${ }^{31}$ In the text, notions of legal culture and legal tradition are used. They are, in fact, notions that are very close to each other. However, in this article the notion of legal culture is used in the way as it was defined in chapter 2. Tradition refers more to the history of a legal system and consists of transmitted information concerning what is law, where we acquire knowledge of it from, and the kind of approaches we should use while seeking information about law, see Husa (n 16) 424. In short, legal tradition is something that forms the in-past foundations of particular legal systems, H Patrick Glenn, 'Doin' the Transsystemic: Legal Systems and Legal Traditions' (2005) 50 McGill LJ 863. However, Glenn wanted to keep these two notions separate, see Glenn, 'Legal Cultures and Legal Traditions' in Mark van Hoecke (ed), Epistemology and Methodology of Comparative Law (Hart 2004). Notwithstanding, here they are seen as necessarily overlapping conceptualisations.

${ }^{32}$ Cf Örücü (n 23) 349.
} 
Conceptualisation requires tools that are provided by Habermas' theory of communicative action, which can be applied when dealing with the legal cultural viability of endemic legal cultures. The following is a brief explanation of certain parts of the theory of communicative action that seek to spell out the role of language in the diffusion of invasive legal species.

Habermas is an outstandingly important social and legal theorist and his theories are extremely broad in their scope of application. Unsurprisingly, a legion of books and articles discuss, praise, and criticise his work. ${ }^{33}$ However, for this study, his contribution is specific and it especially concerns the role of language as the medium of communication and its significance in transmitting a different kind of social structure from one cultural sphere of law to another. ${ }^{34}$

In his theory of communicative action, Habermas presented a very broad general framework that attempted to explain, among other things, how capitalist modernisation produces social pathologies. ${ }^{35}$ The notion of 'lifeworld' occupies a key position in this theory. The idea is to simplify a great deal - that people live their lives within two distinct spheres. These are, firstly, the social sphere which deals with our interactions with family and society in general (social and personal life) and, secondly, the professional and administrative sphere in which people work or interact with institutional authorities (such as the state and the economy). These spheres are called respectively - the lifeworld and the system. ${ }^{36}$

The lifeworld is based on shared meanings and understandings that make it possible to perform actions that others comprehend. In other words, the daily actions that we perform within the lifeworld are, generally speaking, communicative in nature. In contrast, how things work in the system is different because the system deals with strategic action that, in the end, serves the interests of official institutions and organisations. Instead of natural-born social relations, actions in the system are animated by such factors as money and power. In other words, actions in the system are instrumental as to their nature. ${ }^{37}$

The difference between these spheres is fundamental because the aims typical of a system do not coincide with the aims of individuals in their lives in the lifeworld. In the end, actions in the system are strategic actions and they are steps taken in order to achieve specific ends without giving significance to the existence (or lack) of common understandings. Notably, the basis of this theory is embedded in language and, hence, is communicative in the sense that it relies on our

\footnotetext{
${ }^{33}$ For an overview, see The Cambridge Companion to Habermas (CUP 2006).

34 The role of cultural structure in the theory of communicative action, see Jacob Bohman, 'Habermas, Marx, and Social Theory' in Peter Dews (ed), Habermas - A Critical Reader (OUP 1999) 73-4.

${ }^{35}$ Jürgen Habermas, Theory of Communicative Action, Volume I and II (Thomas A. McCarthy tr, Beacon Press 1981).

${ }^{36}$ See Fred R Dallmayr, 'Life-World and Communicative Action', in Bhikhu Parekh and Thomas Pantham (eds), Political Discourse: Explorations in Indian and Western Political Thought (Sage 1987).

${ }^{37}$ Habermas speaks of 'cultural tradition', based on a cultural system of interpretation (Habermas 1981 I) 70-2.
} 
ability to understand (nature, society, ourselves), which arises from our communication with others. $^{38}$

For the discussion on endemic legal cultures and the role of language, the above briefly-explained theory has one particularly relevant dimension. It is the thesis on the colonisation of the lifeworld.

In essence, the lifeworld is a social sphere containing culturally grounded understandings and mutual accommodations. This means that the lifeworld is fundamentally based on shared practices, beliefs, values, and structures of social interaction. The logic underlying communication in the lifeworld is based on these factors. Mostly, what Habermas claims about colonisation of the lifeworld by official systems (ie the economy and the state) entails drastic consequences: it leads to a perversion of public life and politics because of the mixing of the spheres.

Now, spheres are originally separate from each other and communication between them takes place in a restricted manner. However, when the communicative patterns of system (money, bureaucracy) start to invade and subdue the natural communicative patterns of the lifeworld, then the lifeworld begins to transform in the direction of the system ie the lifeworld becomes colonised by the system. Colonisation takes place because, in practice, socially embedded communicative patterns of the lifeworld are overpowered by the alien standards of technical control of the system so that the foundational social logic of the lifeworld changes. As a result, the lifeworld starts to be absorbed by a different type of rationality that is not lifeworld-based but similar to that of the instrumental rationality of the system. Consequently, persons become means to economic and political ends, no longer under their own control. ${ }^{39}$

For the present discussion the most crucial part of the theory is the colonisation thesis - whatever we think of it in general is not of relevance here - and how the changing rationalitymode of language from one sphere has the ability to invade (or colonise) the other sphere. Language itself is not a reason or agent of cultural invasion but a medium through which the colonisation, and gradual takeover, of a different logic of communication, takes place. ${ }^{40}$ Against the backdrop of endemic mixed legal systems, this means that invasive legal species, with their underlying logic that differs from the mixed legal system's logic of law (mixité), can penetrate from a stronger legal culture to an endemic legal culture in the form of language.

\footnotetext{
${ }^{38}$ See Gerard H Fairtlough, 'Habermas' concept of "Lifeworld"' (1991) 4 Systems Practice 547.

${ }^{39}$ See, eg, Hugh Baxter, 'System and Life-World in Habermas' "Theory of Communicative Action"” (1987) 16 Theory and Society 39.

${ }^{40}$ Habermas (1981a I, 101) underlines that communicative action does not equate action with communication. Accordingly, language is primarily a medium of communication.
} 
The diffusion of invasive legal species may start slowly but it tends to speed up when the linguistic barriers are lowered. In other words, the legal language of a mixed legal system may fall into decay and disuse because of its discontinuance as a living, working language of law used by legislators, judges, attorneys, and scholars. The following section will discuss this thesis by looking into four illustrative cases that show different phases of legal linguistic change and range from an almost 'lost' legal culture of mixité to the successful defence of an endemic legal system surrounded by a stronger and potentially invasive legal culture.

\section{Illustrative Cases}

Mixed legal systems may be endemic in the sense that they are surrounded by a competing strong legal culture that produces, knowingly or by accident, an invasive legal species threatening the mixité of a legal system. Likewise, Quebec's civil law is surrounded by the Canadian common law just as Louisiana's mixed legal tradition is surrounded by the American common law. In a similar fashion Chinese socialist-civilian law surrounds Hong Kong's common law, while Scotland's mixed legal tradition is surrounded by the English common law. However, the legal-cultural viability and potential future scenarios for each of these systems looks different.

That said, before going into illustrative cases, a certain caution ought to be kept in mind. That is, the conclusions arising from the illustrative cases discussed here must be interpreted with caution because it is important to bear in mind that the question of legal language and its relation to other languages is a highly complicated phenomenon. From there it follows that this study cannot take into account all the linguistic subtleties of the chosen illustrative cases. Hence, the focus is on the overall view, which means that much by way of nuances cannot be addressed. This is simply because of the complexity of legal language and the number of the interacting layers it involves. The complexity and layered nature of legal language can be illustrated briefly by citing Maitland, who famously noted that the Englishness of English law could be attributed to the peculiar fact that medieval English lawyers actually spoke French in court. ${ }^{41}$ In other words, legal language contains multiple dimensions whose visible surface is only one part of a more complex whole, as the following subsections will show.

\footnotetext{
${ }^{41}$ See John H Baker, 'The Three Languages of the Common Law' (1998) 43 McGill LJ 5, 7 and Caroline Laske, 'Losing Touch with the Common Tongues - the Story of Law French' (2016) 1 Intl J L Discourse 169. See also Mattila (n 1$)$ 309-13. Moreover, the possibility of new 'civil law English' has also been suggested, see John Randall Trahan, 'Levasseur, Legal Linguist' (2016) 76 Louisiana LR 1025, 1036-37.
} 


\section{A Hong Kong}

Comparative law scholars have typically classified Hong Kong as a common law system. However, for the reasons explained below this classification is less accurate today. ${ }^{42}$ In particular, the 'one country, two systems' doctrine means in practice, for comparative study of law, that Hong Kong today should be classified as a mixed legal system fusing together certain elements of mainland Chinese public law with larger portions of common law rules, doctrines, theories and an overall impression of the local legal culture. ${ }^{43}$ In order to be able to explain Hong Kong's legal culturally endemic position as an island of common law surrounded by a socialist version of civil law requires us to start from legal history.

Hong Kong became a British Crown Colony after China ceded Hong Kong Island to Britain in 1842. Moreover, in 1898, China leased the area north of Kowloon to the British for 99 years. In 1982, talks began between China and the United Kingdom concerning the future of Hong Kong. These talks led to the signing of the Joint Declaration on the question of Hong Kong by the respective governments in 1984, which affirmed Chinese sovereignty over Hong Kong from $1997{ }^{44}$ Interestingly, the Handover in 1997 did not mean a drastic change in the nature of the law of Hong Kong. At the same time, though, the ingredients of the legal mixture changed. In principle, the common law system is still arguably in place. ${ }^{45}$ As a Special Administrative Region of China, Hong Kong enjoys autonomous self-rule where human rights and civil liberties should be provided by the Basic Law and enforced by a common law-style judicial system and legal education.

The significance of the past cannot be overlooked here. Hong Kong's past and present is reflected in its mildly hybridised legal system. ${ }^{46}$ In the main, Hong Kong follows the common law tradition, but it must also, in practice, observe the civil socialist legal system of the People's Republic of China. ${ }^{47}$ This statute law-made mixed system is known as the 'one country, two

\footnotetext{
42 There are three Asian common law systems: Hong Kong, Malaysia, and Singapore. For a comparative overview, see Kwai Hang Ng and Bryanna Jacobson, 'How Global is the Common Law? A Comparative Study of Asian Common Law Systems’ (2017) 12 Asian J Comp L 209.

${ }^{43}$ Early account two years after the Handover, Chenguang Wang and Guobin Zhu, 'A Tale of Two Legal Systems: The Interaction of Common Law and Civil Law in Hong Kong' (1999) 51 Revue internationale de droit comparé 917.

${ }^{44}$ In regard to the background, see Yash Ghai, Hong Kong's New Constitutional Order: The Resumption of Chinese Sovereignty and the Basic Law (2nd edn, Hong Kong UP 1999) 1-33.

45 Junwei Fu, 'China' in Jan Smits (ed), Elgar Encyclopedia of Comparative Law (Edward Elgar 2012) 137.

${ }^{46}$ See Ignazio Castellucci, 'Legal Hybridity in Hong Kong and Macau' (2012) 57 McGill LJ 665.

${ }^{47}$ Art 8 Basic Law (The Basic Law of the Hong Kong Special Administrative Region of the People's Republic of China, adopted on 28 June 1990) provides that '[ $t$ ]he laws previously in force in Hong Kong, that is, the common law, rules of equity, ordinances, subordinate legislation and customary law shall be maintained, except for any that contravene this Law, and subject to any amendment by the legislature of the Hong Kong Special Administrative Region.' Moreover, the preamble of the Basic Law states that 'the socialist system and policies will not be practiced in Hong Kong'. At the
} 
systems' doctrine, which means that Hong Kong maintains a capitalistic economic system within the People's Republic of China, which follows a different economic and social system. ${ }^{48}$ Having said that, we need to bear in mind that the system left by the British was not purely a common law tradition, in the sense that it was a colonial legal heritage. ${ }^{49}$ Notwithstanding, it was essentially a common law legal system that became endemic in 1997.

The only official language used in Hong Kong during British rule was English. It was not only the official language that was used in formal contexts but also an elite language that was beneficial in education, career, and business-related contexts. Bilingually trained civil servants acted as a link between the locals and the colonisers. In courts, the locals communicated with judges and counsel through court interpreters. Linguistically, the situation was curious in the sense that people involved with a case spoke Chinese as their first language but the court proceedings took place in the official language: English. It was only in 1974 when Chinese (without specifying which variety) became accepted as a second official language, followed in 1987 when Chinese legislative texts became equally authentic. After the Handover, Hong Kong became the first and only common law system where Chinese is the official language besides English (Singapore has more than two official languages). Consequently, legislation and government communications are published in two languages and court proceedings take place in both English and Chinese. ${ }^{50}$ Moreover, legislative debates take place in Chinese, which has led to suggestions that all monolingually-enacted legislation should be repealed and re-enacted bilingually. ${ }^{51}$ There are also symbolic changes, for instance, Hong Kong Chief Executives use Chinese in their annual policy address. The majority of

\footnotetext{
same time, art 1 of the PRC Constitution provides that ' $[\mathrm{t}]$ he socialist system is the basic system of the People's Republic of China' without mentioning any exceptions. In a formal sense, this seems to place the Basic Law in contradiction to the hierarchically superior PRC Constitution. See for more detailed discussion, Jaakko Husa, 'Accurately, Completely, and Solemnly': One Country, Two Systems and an Uneven Constitutional Equilibrium' (2017) 5 Chinese J Comp L 231.

${ }^{48}$ According to art 5 of the Basic Law, '[t]he socialist system and policies shall not be practised in the Hong Kong Special Administrative Region, and the previous capitalist system and way of life shall remain unchanged for 50 years'. ${ }^{49}$ As noted by Chan, the British heritage is not purely rule of law tradition because 'as in many other colonies, the British in fact created a legal system emphasizing law and order while neglecting the personal liberties and individual rights associated with the common law tradition', Ming K Chan, 'Imperfect Legacy: Defects in the British Legal System in Colonial Hong Kong' (1997) 18 Uni Pennsylvania J Intl L 133, 154.

${ }^{50}$ Basic Law Article 9 provides: 'In addition to the Chinese language, English may also be used as an official language by the executive authorities, legislature and judiciary of the Hong Kong Special Administrative Region.' Official Languages Ordinance Section 3 provides: 'The English and Chinese Languages are declared to be the official languages of Hong Kong for the purposes of communication between the Government or any public officer and members of the public for court proceedings.' See Janny HC Leung, 'Judicial discourse in Cantonese courtrooms in postcolonial Hong Kong' (2012) 19 Intl J Speech, Language and L 239, 240-41.

${ }^{51}$ Janny HC Leung, Statutory interpretation in multilingual jurisdictions' (2012) 33 J Multilingual and Multicultural Development 1, 10.
} 
discussions taking place in the post-handover Legislative Council meetings have been in Chinese; English comes only second. ${ }^{52}$

The existence of two legal languages entails interesting linguistic consequences. Leung has noticed that judges are more formal when they use English whereas when they use Chinese they are more open to 'varied registers and cultural imagination'. ${ }^{53}$ Importantly, the spoken and written forms of Chinese are not the same: the spoken form is Cantonese (a spoken language variety that is the default Chinese in Hong Kong) whereas the written form is Standard Chinese. ${ }^{54}$ The overall view is complicated, although the weakening of legal English seems to be inevitable as the socio-linguistic infrastructure for English weakens and gradually gives way to Chinese. ${ }^{55}$ However, the overall picture is not a simple one and sometimes developments may go in different directions. ${ }^{56}$

Now, the linguistic situation in Hong Kong may undergo colonisation and decolonisation; linguistic colonisation in the form of Standard Chinese and decolonisation in the form of weakening English. ${ }^{57}$ In the colonial period, as noted above, English was a prestigious and high status language, whereas Cantonese was viewed as a lower-level language even though it was widely used in daily communication within the community. Interestingly, during the colonial period the status of Standard Chinese was even lower than Cantonese. After the Handover, a new language policy was adopted, trying to find a balance between Chinese and English. Importantly, written Standard Chinese has been transformed into a legal and official language together with (spoken) Cantonese and English. In practice, English has lost its hegemonic status, and the advantage that it once possessed is diminishing. In the future, it is likely that Standard Chinese will first compete with Cantonese and, in the end, perhaps overtake its position as the main form of Chinese in Hong Kong, as legal, cultural, economic, and political ties with the mainland intensify. ${ }^{58}$ One of the curious outcomes of the language policy is that the relationship between Chinese and English is far

\footnotetext{
${ }^{52}$ Siu-Pong Cheng, Sze-Wing Tang, 'Languagehood of Cantonese: A Renewed Front in an Old Debate' (2014) 4 Open J Modern Linguistics 389, 390.

${ }^{53}$ Leung (n 50) 243.

${ }^{54}$ Hong Kong's Basic Law (Article 9) does not, however, specify which form of Chinese is meant. Article 9 provides that: 'In addition to the Chinese language, English may also be used as an official language...' ('...除使用中文外, 還 可使用英文, 英文也是正式語文’) ie Chinese is referred to as 中文 (zhōngwén/zung1 man4).

${ }^{55}$ Interestingly, in India legal English has not lost its strong position in relation to Hindi, see Mattila (n 1) 338-39.

${ }^{56}$ For a thorough account, see Kwai Hang Ng, The Common Law in Voices - Language, Law and Postcolonial Dilemma in Hong Kong (Stanford Uni Press 2009).

${ }^{57}$ Typically legal dominance also causes linguistic dominance and it could be that standard Chinese becomes a legal lingua franca in certain parts of the world, cf Mattila (n 1) 356.

${ }^{58}$ Cf Liyan Hu, 'Language Policy, Practice and Diglossia in Colonial and Post-Colonial Hong Kong' (2007) 1 Annual of Language \& Politics and Politics of Identity 85.
} 
less contentious than that between Cantonese and Standard Chinese. ${ }^{59}$ The overall situation can be described as the Hong Kong's postcolonial dilemma of bilingualism. ${ }^{60}$

So far, English has retained its position as the leading legal language especially because of its strong position in the higher courts as explained by Leung: 'In the higher courts, English remains the dominant language of proceedings and the preferred language for complicated legal reasoning, given that it is the language in which most lawyers and judges have received their professional training. ${ }^{61}$ Because it is not only about English as an official language but also about English as the inborn language of common law, English will not disappear any time soon. However, common law embedded linguistic culture is slowly changing because of the pressures coming from mainland China, which has a different legal culture than that of Hong Kong. In general, the Chinese legal system can be described as a socialist system of law based primarily on the civil law model. In fact, this is also how China officially regards its system, calling it a 'socialist system of laws with Chinese characteristics'. ${ }^{2}$

Because of the fact that 'one country, two systems' reaches its 50-year limit in 2047 under the Joint Agreement, and because Hong Kong's legal culture is endemic in its relation to China, it is very likely that there will already be a great amount of invasive legal species from the mainland during the transition period. Linguistically these species are in standard Chinese and legally, as to their nature, these species are alien to common law. The route for the invasive species goes through the medium of Chinese, which slowly pushes the formerly leading position of legal English into retreat. This has already taken place in public law, where the significance of Chinese is more important than in the common law tradition anywhere, whereas other areas of law are still very much of the common-law type. Consequently, as whole the legal system of Hong Kong is no longer purely common law, but a hybrid form that mixes common law and Chinese socialist-

\footnotetext{
${ }^{59}$ See Kingsley Bolton, 'Language policy and planning in Hong Kong: Colonial and post-colonial perspectives' (2011) 2 Applied Linguistics R 51.

${ }^{60}$ See $\mathrm{Ng}$ (n 56).

${ }^{61}$ Leung (n 50) 241. Also the fact that there are non-permanent Western judges sitting in Hong Kong courts has an effect on legal language simply because expatriate judges do not normally speak any form of Chinese. Basic Law Art 82 provides that the Court of Final Appeal 'may as required invite judges from other common law jurisdictions to sit on the Court' and Art 92 provides that judges 'shall be chosen on the basis of their judicial and professional qualities and may be recruited from other common law jurisdictions'. For more detailed discussion, see Lin Feng, 'The Expatriate Judges and Rule of Law in Hong Kong: Its Past, Present and Future' in Shimon Shetreet and Wayne McCormack (eds), Judicial Independence in a Globalised World (Brill 2017).

${ }^{62}$ See White Paper on the Socialist System of Laws with Chinese Characteristics (2011) http://www. china.org.cn/government/whitepaper/node_7137666.html4
} 
civilian law. Linguistically, this mixité - English, Standard Chinese, and Cantonese - leads to complicated consequences. ${ }^{63}$

From 1997, legal Chinese has essentially become a kind of "translationese", that is, a specific form of legal language derived from translation of common law English and the bilingual drafting process, also containing Europeanised grammatical style. The result has been puzzling because not only lay people but also legal professionals alike experience significant difficulties in understanding it. Here we can see the problems that are typical of bilingual mixed legal systems: terminological difficulties cannot be avoided. Difficulties arise because many mainland Chinese terms may look like equivalents to Hong Kong "translationese" even though they are not because of the differences between civil law and common law. Accordingly, it has been argued, a gap exists between the two legal cultures and languages. ${ }^{64}$ What is evident, in any case, is further hybridisation of Hong Kong law.

It would be an exaggeration to argue that common law English would have been drastically weakened; hence, today its position still seems relatively secure. Yet, taking into account the fact that mainland China's socialist-civilian system has an inevitable effect on Hong Kong's law, it seems very likely that mainland elements will grow in number and significance in the future with exhilarating speed when the year 2047 approaches. The fact that legal English has already started a slow decline enables the invasive mainland legal species to penetrate the endemic common law of Hong Kong, thus making it more mixed as to its legal cultural nature. The weaker the significance of English as a legal language becomes, the stronger the invasive mainland elements become because Chinese language (in its mainland form) provides a communicative colonisation medium for a different type of legal logic than is the case with common law.

\section{B Scotland}

It is probably not too far-fetched to argue that the Scottish legal system reflects in general the political history of Scots-English relationships, ranging from brutal warfare to relatively recent devolution. ${ }^{65}$ The history of Scots law can be traced back very far in history, at least to the 11th

\footnotetext{
${ }^{63}$ As a result there are linguistic layers so that when courts interpret earlier legislation they give more weight to the original English text because it reflects more accurately the legislature's intent at the time it was originally enacted, see Leung (n 51) 7.

${ }^{64}$ Clara HY Chan, 'Bridging the Gap between Language and Law: Translational Issues in Creating Legal Chinese in Hong Kong' (2012) 58 Babel: an International Journal of Translation 127.

${ }^{65}$ Sue Farran, 'Scotland: Is the Tartan Fading?' in Farran, Örücü, and Donlan (n 24) 13.
} 
century. That is clearly much too broad a period to be dealt with in this study, which has its main goals elsewhere. ${ }^{66}$ Then again, it is possible to distinguish two phases of development that are of particular relevance. The first of these is the long period during which Scotland and England were separate countries and Scotland reached out to the continental European legal tradition that was influenced by Roman law. Then, in 1707, Scotland became part of the United Kingdom although it preserved its legal system, educational system, and church. From there onwards, the English influence became growingly evident in Scots law. Notwithstanding, even before that the Scottish courts were free to borrow or reject English common law as they were, in a similar fashion, to receive or reject continental civil law. Consequently, while modern Scots law has evolved its own rules, doctrines, and theories, these can be traced back to shared common roots with the English system but also much further back to ancient Rome. ${ }^{67}$ Moreover, Scots law also developed its own common law through cases, while it also retained some elements of Scots customary law. ${ }^{68}$

The principles and rules of modern Scots law are drawn from similar sources to those of English law: legislation, the courts, and European law. ${ }^{69}$ Devolution has also had an important impact on Scots law because it means, to simplify a great deal, that Scotland has two governments (Westminster and Holyrood), which are responsible for different areas of governance. ${ }^{70}$ However, from the point view of comparative law, what really tells common law and Scots law apart is the role of so-called institutional writers. In the doctrine of sources of law, institutional writers have a special position as a source of law. The order of importance is legislation, judicial precedent, the institutional writers, custom, and equity. The term 'institutional writers' refers to a number of writings by legal scholars that are identified as formal sources of law. Because Scots law was never codified, unlike on the continent, it has followed the civilian tradition in its own peculiar manner by putting legal cultural faith in such treatises. From the nineteenth century, certain respected Scottish institutional works have been regarded as sources of law. ${ }^{71}$

\footnotetext{
${ }^{66}$ For anyone interested in Scottish legal history, a great amount of material is available in numerous books published by the Stair Society (http://stairsociety.org/publications). The Stair Society is Scotland's leading legal history society (founded in 1934) and one indication of the strong sense of legal history that has, in part, kept the idea of Scots law as a mixed legal system with civilian impact alive.

${ }^{67}$ See Hector L MacQueen, 'Scots Law' in n 45.

${ }^{68}$ Farran (n 65) 14.

${ }^{69}$ For a concise overall view, see Stuart Reid and Janice Edwards, 'The Scottish Legal System' (2009) 9 L Information Management 9.

${ }^{70}$ Applicable legal rules come both from primary and delegated legislation passed by Westminster and the Scottish Parliament. The key legal instrument concerning Scots law is the Scotland Act 1998 (which itself is an Act of the UK Parliament). Section 1 of this Act establishes a Scottish Parliament with a relatively wide range of devolved powers concerning education, the environment, housing and local government. This Act reserves certain matters exclusively to Westminster in the areas of immigration, defence, and foreign policy. Later amendments have extended some of the devolved powers. For a broader discussion on UK devolution, see Peter Leyland, 'The multifaceted constitutional dynamics of U.K. devolution' (2011) 9 Intl J Constitutional L 251.

${ }^{71}$ See John W Cairns, 'Institutional writings in Scotland reconsidered' (1984) 4 J L History 76.
} 
These important scholars wrote books setting out the principles on which Scots legal culture is based. The connection to civil law is clear with these writers because much of their writings were based on Roman law. Now, there are several institutional writers but the main ones are Stair, Bell and Erskine. Of these scholars, Stair is thought to be the most central institutional writer. His Institutions has even had a profound impact on the development of certain fields of Scots private law. ${ }^{72}$ At the same time, the overall picture is nuanced. For instance, development in the area of criminal law has been different not only from English common law but also from other areas of Scots law. ${ }^{73}$

From the point of view of comparative law, Scotland is still classified as a mixed legal system; notwithstanding, there has been a longstanding unresisting mentality towards English common law. ${ }^{74}$ Partially, it seems, this mentality has been aided by legal language in that legal practice and teaching of law takes place in English. The significance of Latin has been diminishing strongly. Notwithstanding, much of Scots legal language, such as legal terms, may be unfamiliar to English lawyers. ${ }^{75}$ That said, Scotland seems to be in fact a monolingual jurisdiction and in accord with English common law. Although English is the dominant language of private and public discourse, there are other linguistic layers too: Scots vernacular, Gaelic, and the diverse language of immigrant communities. ${ }^{76}$ In a historical view, then, there are linguistic layers other than English, of which Latin has had the greatest impact on Scottish legal language. But there are also other perhaps more surprising layers like Dutch, French, and the Celtic languages. ${ }^{77}$ It has been noted that, even before the strong English common law influence after 1707, Scots legal language contained elements of indigenous law and external influences. So, influences did not come solely from English common law but also from Scandinavian law, continental Roman law, and canon law. ${ }^{78}$ It is quite possible, then, that Scots law, from the Middle Ages, has actually been a mixed system,

\footnotetext{
${ }^{72}$ For detailed discussion, see DM Walker, The Scottish Jurists (Green \& sons 1985).

${ }^{73}$ See, eg, Lindsay Farmer, 'The Genius of our law...Criminal Law and the Scottish Legal Tradition' (1992) 55 MLR 25. 
meaning that it has been open to influences both from English common law and continental civil law. $^{79}$

The long historical path alongside English common law culture has significant consequences. After a long period of invasive common law species, aided by common legal language, the mixed nature of the Scottish legal system seems to be at risk. ${ }^{80}$ This does not mean, however, that Scottish mixed legal culture would be meaningless; on the contrary. In comparison to Wales, Scotland stands out in the sense that law has played a role in its sense of national identity from the Middle Ages until today. ${ }^{81}$ The weight of the idea of a special Scottish national identity has been clear, especially in the area of Scots criminal law. ${ }^{82}$ Yet at the same time, there has been much by way of adaptation, transplants, and pragmatic reception, which diminishes the mixité of legal culturally endemic Scots law. ${ }^{83}$

The outcome, similar as in the case of invasive species, is that Scots law has become culturally very close to English law. Arguably, it has been legal culturally colonised because of invasive legal species from English law. It has been noted that it would not be immediately obvious to 'the outsider' that the law was drawn from different legal families. ${ }^{84}$ Socio-linguistic factors are of importance here because English is the official language in Scotland, which makes it very difficult for Scots lawyers to acquire knowledge of historical or modern civil law because they are behind the language barrier. ${ }^{85}$ Then again, this has also to do with the legal mentality and political will to preserve the mixité of Scots law. ${ }^{86}$ Of course, Scotland's potential independence or changing intensity of devolution may change some of this. ${ }^{87}$

Nevertheless, it is necessary to tread carefully with the argument on legal language. It is not argued here that the soul of Scots law would not be legal culturally civilian. This legal cultural soul seems real and we can see it in many places, such as in the idea of private law

\footnotetext{
${ }^{79}$ See WDH Sellar, 'Scots Law: Mixed from the Very Beginning? A Tale of Two Receptions' (2010) 14 Edinburgh LR 3.

${ }^{80}$ Common language has had an important role in this, see MacQueen (n 67) 791 (refers to $19^{\text {th }}$ century reception of English law).

${ }^{81}$ See for a broader discussion, Hector L MacQueen, “"Regiam Majestatem”, Scots Law, and National Identity' (1995)

74 Scottish Historical R 1.

${ }^{82}$ Farmer (n 73) speaks of imaginary past of Scottish criminal law as an invented tradition.

${ }^{83}$ It has been argued that the mixite of the Scottish legal system is weak in the sense that it is vulnerable to reception and imposition from other legal systems, see Robin Evans-Jones, 'Receptions of Law, Mixed Legal Systems and the Genius of Scots Private Law' (1998) 114 LQR 228.

${ }^{84}$ Farran (n 65) at 33.

${ }^{85}$ Tetley (n 26) 731 (citing Evans-Jones). Reid points out that even prior to 1707 English was 'the main language in Scotland, with only about a quarter of the population speaking Gaelic', Reid, 'Scotland' in n 8, 222.

${ }^{86}$ For a more detailed discussion, see Andreas Rahmatian, 'The Political Purpose of the 'Mixed Legal System' Conception in the Law of Scotland' (2017) 24 Maastricht J Eur Comp L 843.

${ }^{87}$ As Hector L MacQueen notes, 'In devolved Scotland, the fate of private law is now no longer a matter predominantly for the courts and text writers', MacQueen, 'Scots and English Law: The Case of Contract' (2001) 54 Current L Problems 205, 228.
} 
codification that still seems to have support in Scotland, which is different from the legal cultural attitude on the common law side. ${ }^{88}$ Notwithstanding, the common law approach has, if not in substance, been strong in Scots criminal law. ${ }^{89}$ Albeit, arguably it has become increasingly difficult to keep the civilian soul alive mainly because English common law and Scots law both 'speak' English. ${ }^{90}$ At the same time, we need to keep in mind that on the level of terminology and doctrine, English law and Scots law do not speak exactly the same language. However, in the sense of legal cultural colonisation and invasive legal species there is enough linguistic commonality for the invasive species to displace or crowd out native endemic legal species. ${ }^{91}$ Accordingly, the impact of English law has been increasingly powerful from the mid eighteenth century onwards as the Scots courts frequently cite English authority. ${ }^{92}$

The level of mixité in law is also, at least indirectly, related to the lack of viability of Scotland's indigenous languages (Scots and Gaelic languages) that are in a precarious position because of the overwhelming presence of English. ${ }^{93}$ As a result, the mixité of Scots law is at risk and English as the medium for legal communication plays a crucial role in this respect.

\section{Quebec}

Quebec is part of Canada, a province with a French-speaking majority, culture, and tradition of civil law. From the point of view of legal language it is of importance that even though Canada is officially a bilingual country (French and English), Quebec is officially a monolingual province; the only official language of Quebec is French. ${ }^{94}$ As we will see below, this fact has tremendous importance for Quebec's ability to deflect and transform invasive common law legal species.

\footnotetext{
${ }^{88}$ See, eg, Martin Hogg, 'Codification of Private Law: Scots Law at the Crossroads of Common and Civil law' in Kit Baker, Karen Fairweather, Ross Grantham (eds), Private Law in the $21^{\text {st }}$ Century (Hart 2017). See also Andreas Rahmatian, 'Codification of private law in Scotland: observations by a civil lawyer' (2004) 8 Edinburgh LR 28. ${ }^{89}$ See, eg, James Chalmers, 'Developing Scots Criminal Law: a shift in responsibility?' (2017) Juridical R 33 (pointing out that there is a certain 'legislation scepticism').

${ }^{90}$ See John WG Blackie and Niall R Whitty, 'Scots Law and the New Ius Commune' in Hector L MacQueen (ed), Scots Law into the $21^{\text {st }}$ Century (W Green 1996) 81.

${ }^{91}$ Cf Robin Evans-Jones, 'Civil Law in the Scottish Legal Tradition' in Robin Evans-Jones (ed), The Civil Law Tradition in Scotland (The Stair Society 1995) (arguing that the accessibility of common law is due to the fact that language plays a crucial role ie English law would not have spread so easily if there had been a language barrier).

${ }^{92}$ Reid (n 85) 272.

${ }^{93}$ See Catherine Matheson and David Matheson, 'Languages of Scotland: Culture and the Classroom' (2000) 36 Comp Education 211.

${ }^{94}$ Nunavut, however, is officially trilingual because the indigenous language of Inuktitut has a position as an official language besides English and French. Official Languages Act (S.Nu. 2008, c.10), Art 3(1) 'The Inuit Language, English and French are the Official Languages of Nunavut'.
} 
From the point of view of comparative law, there are two underlying distinctive features in the Canadian legal system. These are bijuralism and bilingualism, which together make the unique bilingual bisystemism of Canadian law. Both of these features result from the history of Canada. Colonial history provides two legal culturally different bases for Canadian law. The constituent parts are based on the English and French systems. Broadly speaking, we can say that colonists brought these legal cultures to Canada in the 17th and 18th centuries. However, these legal cultures (or systems) are not on an equal footing because after the Battle of Quebec in 1759, the country fell under English common law, except for Quebec itself, which follows civil law even today. ${ }^{95}$ Due to the colonisation of North America by France and Great Britain, the system is bijural, which in turn has several linguistic consequences. For instance, bilingualism also means bilingualism in the language of law. This can be seen in the drafting of federal legislation, which needs to be comprehensible to Canadian citizens, that is to say, legislation is in both English and French, following the respective languages of common law and civil law legal cultures. The idea of bijural bilingualism means that legislation and federal judicial decisions are produced in both English and French. ${ }^{96}$ However, as noted above, Quebec's sole official language is French.

As a result, Quebec is different from the rest of the country and its civilian features tell its legal culture apart from the rest of Canada. In this regard, Quebec is legal culturally very close to other systems that follow the French, Dutch, German, Spanish or Portuguese civil law legacy. Because civil law systems are essentially codified systems originating from Roman law, they rely on codes. Therefore Quebec is the only province with a civil code. This civil code is based on the French Code Napoléon. ${ }^{97}$ Notwithstanding, it would not be accurate to describe the Quebec legal system as a purely civilian legal system but rather a mixed legal system that can be described in terms that conceptualise this mixité..$^{98}$ Part of the mixed legal system and its legal culture consists

\footnotetext{
${ }^{95}$ Quebec's mixité was founded only when the sovereignty of Nouvelle France was transferred from France to England, Michel McAuley, 'Quebec' in n 8, 354-55.

${ }^{96}$ Constitution Act Section 133 provides: 'Either the English or the French Language may be used by any Person in the Debates of the Houses of the Parliament of Canada and of the Houses of the Legislature of Quebec; and both those Languages shall be used in the respective Records and Journals of those Houses; and either of those Languages may be used by any Person or in any Pleading or Process in or issuing from any Court of Canada established under this Act, and in or from all or any of the Courts of Quebec.' Supreme Court Act (R.S.C., 1985, c. S-26) Section 6 provides: 'At least three of the judges shall be appointed from among the judges of the Court of Appeal or of the Superior Court of the Province of Quebec or from among the advocates of that province.' See for more detailed discussion, Roderick Macdonald, 'Legal Bilingualism' (1997) 42 McGill LJ 119.

${ }^{97}$ However, it should be noted that there are differences between legal French in France and in Quebec, see Mattila (n 1) 255 .

${ }^{98}$ Michel Morin compares Quebec to different mixed systems of law (Hong Kong, Macau, South Africa, and Israel) and uses such terms as dualism, l'hybridité, bijuridisme, and mixité to describe the mixed nature of the legal system. See Morin, 'Dualisme, mixité et métissage juridique: Québec, Hong Kong, Macao, Afrique du Sud et Israël' (2012) 57 McGill LJ 645.
} 
in the fact that there are diverse tendencies and rich crossovers. ${ }^{99}$ In practice, new legal concepts are created because of the interaction between common law and civil law. ${ }^{100}$

We may characterise the Quebecois legal system as 'a real jungle as a result of its mixed origins'. ${ }^{101}$ Importantly, it is not only about the mixture of common law with civil law, but also about the mixture between a federal state and broad powers of the province, with the addition of dimensions of indigenous law. As a Province, Quebec is subject to common law-based public law that also governs certain parts of private law such as bankruptcy and divorce. ${ }^{102}$ On the other hand, the overall picture is more nuanced than this because it may also be the case that federal parts of private law are supplemented by civil law because of gaps in federal legislation. This kind of a mixing-friendly-mentality is different from earlier years when the language (French) and sense of cultural identity were more deeply intertwined with a stricter form of Quebecois legal nationalism. ${ }^{103}$ Overall, there is no general feeling in Quebec legal circles that its mixed legal system would be in danger because of invasive legal species from Anglophone common law, even though appointments of monolingual Anglophone judges to the Supreme Court of Canada have raised certain worries concerning bijuralism and bilingualism. ${ }^{104}$ Because Quebec is monolingual and the surrounding legal system bilingual, there is no direct linguistic (or communicative) route for invasive legal species to colonise Quebecois legal culture.

That said, there is no denying that there are invasive legal species. The real question, though, is why these invasive common law species pose no serious threat to the mixed nature of the Quebec legal system. Undoubtedly, the answer lies in the strong legal-linguistic viability of Quebec's legal heritage: it is able to absorb common-law invasive species and transform them into a part of its endemic legal culture. This is because of the resilience of Quebec's mixité: 'the mixed nature of Quebec private law is the key to its legal identity'. ${ }^{105}$ This fits well together with the observation that Canadian jurists seem to accept the idea according to which federal law needs to be harmonised with the common law and the civil law even though there is no consensus as to where the duty actually lies: Parliament or provincial legislatures. ${ }^{106}$ In addition, the final obstacle for

\footnotetext{
${ }^{99}$ Robert Leckey, Prescribed by Law/Une Règle de Droit' (2007) 45 Osgoode Hall LJ 571, 618.

100 McAuley (n 95) 372.

101 Sophie Morin, 'Quebec' in n 24, 165.

${ }^{102}$ However, the assumption according to which Canadian public law would derive uniformly from British law can be criticised, see Leckey (n 99).

${ }^{103}$ Morin (n 101) 169.

${ }^{104}$ See, eg, David Schneiderman, 'Canadian Judicial Nomination Process and the Press' (2014) 4 Õnati Socio-Legal Series 685, 696-97.

${ }^{105}$ Morin (2014) at 181. Leckey (n 99, 618) says that 'Multiple identities are richly evident in Canadian law'.

${ }^{106}$ Leckey (n 99) 615-16.
} 
invasive legal species is in French-speaking law that makes it difficult for common law to directly penetrate Quebec's legal culture, especially in the field of private law. ${ }^{107}$

What remains clear is why Quebec's mixité and in particular its endemic civilian tradition are able to remain distinct from the surrounding common law has to do with language. Quebec's legal language is based on French as a different language from the English of surrounding common law. It is not merely a linguistic difference because there is a deeper cultural function as French serves to ensure that lawyers are aware of their tradition's distinctiveness and separation from the common law. More broadly, it can be argued that civilian legal language is important for the continued viability of a mixed system that is surrounded by another legal culture. What is more, as a province, Quebec can communicate with Canada using French, the same language that has a steady socio-linguistic embedding in the province. This is important, because it provides a genuine legal cultural protection for the endemic mixed legal system against the surrounding common law; French is a living legal language, it exists beyond translation - it is the communicative medium used by Quebec lawyers. This is crucial, because if an endemic legal language starts to rely on translations, then it becomes increasingly difficult to maintain its mixité, as is the case with Louisiana. ${ }^{108}$

However, it is important to grasp that a language in itself does not suffice to ensure the viability of a mixed system. The strength of Quebec French as a medium for legal communication can be seen in how it actually influences Quebec English and not the other way around. ${ }^{109}$ Along similar lines, besides Quebec we can mention the somewhat unique case of bilingual New Brunswick where common law is taught solely in French ('la common law en français') at the Faculty of Law at the Université de Moncton. ${ }^{110}$ In any case, as Quebec shows, what is needed is a socio-linguistic infrastructure that ensures the continued viability of the endemic legal system. In the case of Quebec, this can be described in the following manner:

'Both the historic languages of the civil law and the common law in fact continue to be read, understood, spoken and written by Quebec's legislators, judges, lawyers and scholars. Law students must have a solid command of both French and English in

\footnotetext{
${ }^{107}$ As McAuley (n 95, 376) points out 'There are very few English-speaking jurists working in the private law field today'.

108 See Rosalie Jukier, 'Canada’s Legal Traditions' (2018) 11 Civil L Studies 75, 90-1.

${ }^{109}$ See Shana Poplack, James A Walker, and Rebecca Malcolmson, ‘An English "like no other”?: Language Contact and Change in Quebec' (2006) 51 Canadian J Linguistics/R canadienne de linguistique 185. In the field of law, 'original sources in French are fully accessible, even to English speakers, who must be effectively bilingual', McAuley (n 95) 377.

110 'La Faculté de droit est d'abord un établissement d'enseignement de la common law en français. C'est là sa mission' https://www.umoncton.ca/umcm-droit/node/84
} 
order to pursue legal studies in Quebec in either of those tongues and in order to practise effectively at the Bar and on the Bench in the province.' 111

The case of a lacking socio-linguistic infrastructure is addressed in the following section.

\section{Louisiana}

Louisiana is a state and part of the United States but it is also a mixed legal system in the sense that its legal culture is based on civil law. Historically speaking the civil law features of Louisiana come from its colonial past. It has been a possession of two countries that are civil law countries: Spain and France. At the same time, Louisiana is part of the United States of America that, by and large, relies on the common law tradition. Accordingly, we may regard Louisiana's legal system as a mixité consisting of both common law and civil law influences and features. The civil law tradition is less clear in the area of public law, as is the case with Quebec, and Louisiana's private law is more evidently based on French and Spanish civil law traditions that are, in turn, both ultimately based on the Roman law heritage. Notwithstanding, as already stated, Louisiana's public law is heavily influenced by the federal public law of the United States. Moreover, Louisiana civil procedure law is consistent with the Federal Rules of Civil Procedure. ${ }^{112}$

From the point of view of legal culture, Louisiana is an endemic legal system or, more poetically, 'Alone in the common-law ocean of these United States, Louisiana is an island of civil law'. ${ }^{113}$ Linguistically this endemism has a consequence that can be seen in the flood of invasive common law species entering the mixed system of Louisiana. Lacking its own legal language, it is difficult for Louisiana to block impulses coming from the surrounding bigger legal culture. In practice, this means that common law legal terminology is used increasingly as a direct result of the legal cultural influence from the other states and the federation.

In any case, in order to conceive the roots of mixité in Louisiana's law, we need to look back at the earlier phases. There we find a similar type of colonial history as was the case with Quebec. To simplify, during the seventeenth century France expanded its reach in America by spreading into the unexplored western frontiers. Back then, France was securely established in

\footnotetext{
111 Tetley (n 26) 727.

112 Being consistent is, however, not the same thing as being identical. Much of Louisiana's Rules of Civil Procedure are modelled after the federal rules, yet Louisiana has its own civilian type of Code of Civil Procedure. For a broader discussion with a historical account, see Henry G McMahon, 'The Louisiana Code of Civil Procedure' (1960) 21 Louisiana LR 1 (explaining also the history of French, Spanish, Roman, and common law mixture).

${ }^{113}$ N Stephen Kinsella, ‘A Civil Law to Common Law Dictionary’ (1994) 54 Louisiana LR 1265, 1265.
} 
Quebec. Next, the French moved into the Great Lakes region and along North America's great rivers that acted as natural highways both for explorers and fur traders. Towards the end of the seventeenth century, French interest was focusing on the lower Mississippi river country that had been left virtually untouched by other Europeans. ${ }^{114}$

After various phases and developments in French colonisation, the French population and power in Louisiana increased but never to viable levels. As a result, the colonising attempt was economically in difficulties. Consequently, France ceded Louisiana to Spain via the Treaty of Paris (1726). Therefore, Louisiana was legally Spanish but its population remained culturally and linguistically French. Notwithstanding, Spain experienced similar difficulties to the French and could not maintain its colonial rule over Louisiana. Accordingly, Louisiana returned to France in 1803. From there on, the French-Louisianans were worried about their legal culture and the invasive power of English common law. Their fear of invasive legal species was not exaggerated since English-speaking American common law migrated to Louisiana along with people: common lawbased rules and customs embedded in English language began to intermingle with the French language and continental European legal tradition, creating a legal mix. ${ }^{115}$ In retrospect, the nineteenth century was the decisive period of linguistic transformation. The de facto practice of publishing laws in two languages ceased: 'As the state became increasingly Anglophone, the publication of the laws in French was finally abandoned'. ${ }^{116}$

In the constitutional history of Louisiana, there are many layers in which the position and role of the French language kept changing, yet the direction of development was evident throughout the process. French was the outgoing language of law and the socio-linguistic infrastructure of French language was on the retreat, whereas the common law - aided by the growing usage of English - was advancing. Finally, an important event occurred in 1921 when the state Constitution ruled that the English language alone was to prevail in the legislature and the courts of Louisiana. Under the 1974 Constitution, the present state Constitution, there is no separate provision on the official language or the language of the legislature or the courts. In practice, this means that English alone is the official language. Notably, the courts are modelled on the common law scheme, while judges think and act like common law judges. ${ }^{117}$ This has consequences for the socio-linguistic infrastructure of an endemic legal system. Simply put, there is no genuine need for lawyers, legislators, judges, or even law professors or students to have even a passive reading

\footnotetext{
${ }^{114}$ Roger K Ward, 'The French Language in Louisiana Law and Legal Education: A Requiem' (1997) 57 Louisiana LR 1283, 1287-9. 
knowledge of French for completing their training and to practise their professions. So, even though some of the significant French civil law treatises have been translated into English, these books are consulted only in their translated English forms. ${ }^{118}$ Communicative contact with legal French is, therefore, indirect. ${ }^{119}$

As pointed out above, legal language does not exist in a vacuum but is a part of the surrounding social reality, while a system's ability to exist and survive are certainly not solely linguistic factors. The significance of legal French is, of course, deeply related to the more general position of Louisiana French. The fact remains that the decline of French accelerated at the end of the 19th century, resulting in the situation today, when Louisiana French is a moribund language; still spoken by about 130000 speakers, with differing grades of proficiency, though. The development of Louisiana French is connected to Louisiana's distinctive societal and linguistic ecosystem that was characterised by a mixed society. Notably, the continuing contact with English takes place in an entirely different linguistic-ecological frame, which results in the ongoing attrition of Louisiana French. ${ }^{120}$ This is enhanced by the absent linguistic resilience of the civilian legal tradition, unlike in Quebec. Ethnolinguistic research showed already more than twenty years ago that youths of Cajun and French descent were not able to transmit the French language to their children. ${ }^{121}$ All in all, we can say that Louisiana's mixité is situated in a monolingual society even though there are still some Francophone pockets in the state. ${ }^{122}$

In short, because there is no real use of legal French and the socio-linguistic infrastructure is lacking, then, as a result Louisiana lawyers cannot read original French texts. Moreover, legal publishing in the state is exclusively in English. ${ }^{123}$ These socio-linguistic factors contribute to the frailty of the civil law tradition in Louisiana. ${ }^{124}$ Accordingly, we can argue that '...the difficulty which the civilian tradition experiences in surviving and developing in Louisiana is

\footnotetext{
${ }^{118}$ Carbonneau says that '... there is little in the way of linguistic or cultural ties to the parenting civilian legal systems in Europe. This has contributed significantly to the retrenchment of the civil law culture in Louisiana, relegating it to a primarily historical relevance. As a result, there is a growing sense of isolation, defensiveness, and insecurity among civilians in Louisiana', Thomas E Carbonneau,'The Survival of Civil Law in North America: The Case of Louisiana' (1992) 84 L Library J 171, 174. See also Palmer and Borowski (n 115) 348.

${ }^{119} \mathrm{Cf}$ Palmer and Borowski (n 115) $346 \mathrm{fn} 337$. Yet, there are efforts to produce an unofficial French translation of the Civil Code as evidence that there is some attempt to resist the disappearance of the civilian tradition, see Matthew Boles, 'Turning Gumbo into Coq au Vin: Translating the Louisiana Civil Code' (2019) 5 Italian L J J 45.

${ }^{120}$ See Ingrid Neumann-Holszchuh, "“Carrefour Louisiane”. Aspects of Language Contact in the History of Louisiana French' (2014) 7 J Language Contact 124.

${ }^{121}$ See Rodrigue Landry, Real Allard and Jacques Henry, 'French in South Louisiana: Towards Language Loss' (1996) 17 J Multilingual and Multicultural Development 442.

122 Palmer and Borowski (n 115) 346.

${ }^{123}$ Lorio discusses obstacles to the strengthening of the civil law and notes that 'the fluency in the French language has diminished over the last sixty-five years. Fewer of our students are bilingual, and of the few who are, their second language is usually not French', Kathryn Venturatos Lorio, 'The Louisiana Civil Law Tradition: Archaic or Prophetic in the Twenty-First Century?' (2002) 63 Louisiana LR 1, 22.

124 Tetley (n 26) 730.
} 
directly proportional to the constantly declining use of the French language in that state'. ${ }^{125}$ This take is not very hopeful concerning the future of Louisiana's endemic mixed law; however, it is not the most gruesome. This view from 1997 is, perhaps, the gloomiest:

'Once a glorious and indispensable part of Louisiana's legal tradition, French is now a legal Nosferatu, a dead creature, unable to find a final resting place, which walks among and preys upon the living. Banished from the State constitution, exorcized from the State's procedural scheme, and no longer the language of the Louisiana Civil Code, French, notwithstanding its obvious demise, still obstinately manages to exert some influence, albeit Lilliputian, over Louisiana law. Inevitably, this influence will disappear as Louisiana law becomes increasingly folded into mainstream AngloAmerican common law.' ${ }^{126}$

\section{Conclusion}

This study was designed to determine the effect of language on the viability of mixed legal systems. The discussion began by stating that the relation between law and language in general is an important phenomenon, well-known in the study of law. Moreover, the fact that the role of language is exceptionally important for the viability of mixed systems was underlined. Against the backdrop of mixed law, Tetley in particular has pointed out that language is important for a mixed jurisdiction in the sense that there must be two official and living languages in order for two legal systems to be preserved so that their genius and tradition underlying each system can remain viable. On the other hand, 'the existence of only one official language in a mixed jurisdiction tends to foster the erosion of any legal system other than the one of which that language is the principal medium of expression'. ${ }^{127}$

This article built on that important observation, discussing and analysing it by applying the ecological conceptualisation of endemism and invasive species, and explaining the process by which invasive species are able to colonise an endemic mixed legal culture. A certain caution is needed here, however. It should go without saying that legal systems can be endemic only to a limited extent, yet the idea of some kind of legal cultural endemism seems to fit reasonably well with many mixed systems especially when we look at those systems from the viewpoint of legal language. The findings from the above cases suggest that it is possible to speak of a legal linguistic endemic dimension that does not, nevertheless, equate to full legal cultural endemism.

\footnotetext{
125 ibid 729.

${ }^{126}$ Ward (n 113) 1319.

127 Tetley (n 26) 732.
} 
Based on the above analysis it would seem that having an official position as a legal language alone would not suffice because what is needed is a socio-linguistic infrastructure that ensures the use of a minority legal language differing from the language used in the surrounding non-endemic legal culture. Borrowing from ecology, this article has shown that invasive legal species possess the potential to change habitats and alter the way in which a mixed legal system functions and to displace or crowd out native endemic legal species, thus creating a new legal cultural structure. This process of displacement or crowding out takes place in a manner that is similar to the process of colonisation of the lifeworld as explained by Habermas in his theory of communicative action. Essentially, language can be both an obstacle and an enabler for invasive legal species exported or imported from a surrounding bigger legal culture. One of the more significant observations to emerge from this study is that language itself is not the cause of legal cultural colonisation; instead, language is the medium through which invasive legal species are carried in communicative action taking place between systems. Overall, the four above illustrations support the view that underlines the exceptional importance of legal language for mixed legal systems. ${ }^{128}$

The table below presents the above discussed on the illustrative cases.

\begin{tabular}{|l|l|l|l|l|l|}
\hline System & Status & $\begin{array}{l}\text { Mix } \\
\text { (major/minor) }\end{array}$ & $\begin{array}{l}\text { Legal language } \\
\text { (major/minor) }\end{array}$ & $\begin{array}{l}\text { Socio- } \\
\text { linguistic } \\
\text { infrastructure } \\
\text { for major } \\
\text { language }\end{array}$ & $\begin{array}{l}\text { Ability to resist } \\
\text { colonisation/invasive } \\
\text { species }\end{array}$ \\
\hline $\begin{array}{l}\text { Hong } \\
\text { Kong }\end{array}$ & $\begin{array}{l}\text { Special } \\
\text { Administrative } \\
\text { Region }\end{array}$ & $\begin{array}{l}\text { common } \\
\text { law/Chinese } \\
\text { law }\end{array}$ & $\begin{array}{l}\text { English/Chinese } \\
\text { (unspecified) }\end{array}$ & $\begin{array}{l}\text { Strong } \\
\text { English, signs } \\
\text { of weakening }\end{array}$ & $\begin{array}{l}\text { Relatively strong, } \\
\text { mainland effect } \\
\text { growing, 2047 } \\
\text { approaching }\end{array}$ \\
\hline Scotland & Part of the UK & $\begin{array}{l}\text { common } \\
\text { law/civil law }\end{array}$ & English/ - & Strong English & Weak \\
\hline Quebec & $\begin{array}{l}\text { Province of } \\
\text { Canada }\end{array}$ & $\begin{array}{l}\text { civil } \\
\text { law/common } \\
\text { law }\end{array}$ & French/English & $\begin{array}{l}\text { Strong French } \\
\text { (sole official } \\
\text { language) }\end{array}$ & Strong \\
\hline Louisiana & $\begin{array}{l}\text { State in the } \\
\text { United States }\end{array}$ & $\begin{array}{l}\text { common } \\
\text { law/civil law }\end{array}$ & English/ - & Strong English & Weak \\
\hline
\end{tabular}

One obvious key factor for viability that the above table reveals concerns legal language. The existence and strength of a legal language different from the surrounding non-endemic legal culture

128 Of course, this is not the case only with mixed systems. Baker (n 41, 7) points out that 'common law could never have become a distinct body of law without its own distinct language - a terminology different from that of ancient Rome - in which to express its concepts.' 
that produces invasive legal species is of importance. Crucially, it is not only about the existence of legal language as such but, rather, about the existence of a socio-linguistic infrastructure. It seems obvious that strong bilingualism supported by legal, social, cultural, and political factors is needed if a system seeks to maintain its legal cultural mixité. Quebec is an example of this, as has been the case with Hong Kong, at least so far. If there is no different legal language from that of the surrounding legal culture, then it becomes very difficult to maintain the mixité of a system, as we can see in the case of Scotland. On the other hand, the case of Louisiana shows that some kind of existence of a legal language other than the surrounding one is not enough to maintain the mixite of a legal system if the supporting socio-linguistic infrastructure is insufficient.

The above observations have significant implications for the understanding of what is the exact role of legal language for mixed legal systems and their potential viability. Instead of merely registering the significance of legal language for legal systems, endemism - combined with the theory of communicative action - contributes to our understanding of the role of legal language in the diffusion and transformation of law in general. Notwithstanding the relatively limited sample of cases, the above points offer insights into the viability of mixed legal systems and how their viability is necessarily intertwined with legal language.

We can also draw a concrete conclusion concerning policy choices for endemic mixed legal systems. If the viability of a mixed legal system is to be preserved, then a key policy priority should be to plan for the long-term care of the socio-linguistic infrastructure of a legal language different from the surrounding bigger legal culture. For instance, for Hong Kong this would mean policy choices in terms of keeping English as a living language of law in order to ensure the viability of the common law tradition. For Quebec the situation is simpler in the sense that they just need to keep doing what they are already doing concerning the viability of legal French in the province. For Louisiana and Scotland, the challenges are bigger because their legal language is the same language as is used by the surrounding non-endemic legal culture. Albeit, the measures would be rather similar in the sense that they would need to obtain more linguistic proficiency in civil law languages in order to keep the legal cultural contact alive and not allow it to fall into the status of a curiosity. Nevertheless, of course, because there is no socio-linguistic infrastructure, keeping the endemic legal culture alive is a very tall order indeed. As Heraclitus once said, 'You cannot step twice into the same river'. ${ }^{129}$ This is also the case with legal languages; they evolve and transform

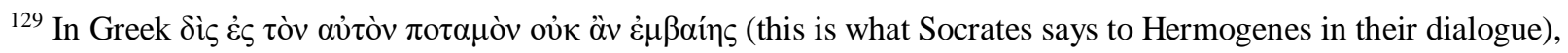
Plato in Twelve Volumes, Vol 12 (Harold N. Fowler tr, Harvard Uni Press 1921).
} 
over time. Then again, reviving even a dying language is not totally impossible. ${ }^{130}$ Accordingly, in the case of common law and civil law, re-building the required socio-linguistic infrastructure is far from impossible simply because the legal languages of both common law and civil law are very much alive.

${ }^{130}$ See, eg, Brad Montgomery-Anderson, ‘A Model for Indigenous Language Revival' (2008) 6 Indigenous Nations J 23. 